\title{
Assessment of In-Place Oil Shale Resources of the Green River Formation, Greater Green River Basin in Wyoming, Colorado, and Utah
}

\section{Introduction}

The U.S. Geological Survey (USGS) recently (2011) completed an assessment of in-place oil shale resources, regardless of grade, in the Eocene Green River Formation of the Greater Green River Basin in southwestern Wyoming, northwestern Colorado, and northeastern Utah (fig. 1). Green River Formation oil shale also is present in the Piceance Basin of western Colorado and in the Uinta Basin of eastern Utah and western Colorado, and the results of these assessments are published separately (Johnson and others, 2010a, 2010b). No attempt was made to estimate the amount of oil that is economically recoverable because there has not yet been an economic method developed to recover the oil from Green River Formation oil shale.
Figure 1. Map showing boundary (in red) of the Greater Green River Basin in Wyoming, Colorado, and Utah, which incorporates the Green River, Great Divide, Washakie, and Sand Wash Basins. Boundary of the Greater Green River Basin is the same as that for the Southwest Wyoming Province (Southwest Wyoming Province Assessment Team, 2005). Also shown are county lines, townships, major structures and uplifts, drill holes with oil shale information, areas underlain by oil shale-bearing rock, and location of cross section in figure 2. Structure contour map on the top of the Mesaverde Group is from Finn and others (2005).

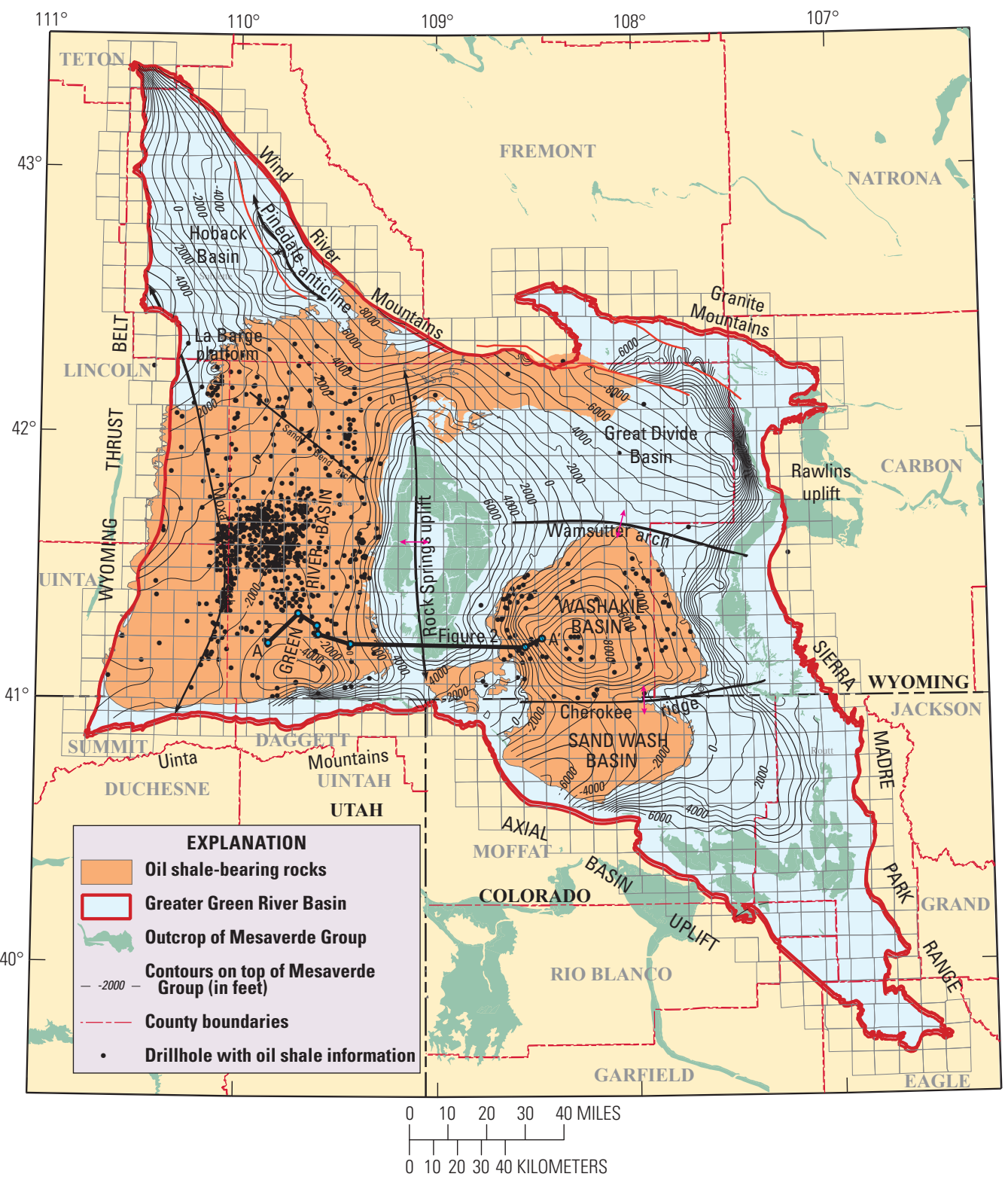




\section{Methodology}

Oil yields were measured using the Fischer assay method, a standardized laboratory test for determining the oil yield from oil shale that has been almost universally used to determine oil yields for Green River Formation oil shales (Stanfield and Frost, 1949; American Society for Testing and Materials, 1980). Fischer assay does not necessarily measure the maximum amount of oil that an oil shale can produce, and there are retorting methods that yield more oil. However, the oil yields achieved by other methods typically are reported as a percentage of the Fischer assay oil yield; thus Fischer assay still is considered the standard by which other methods are compared. In this assessment, a spatial interpolation and extrapolation method for producing resource maps and computing resource volumes was used - the Radial Basis Function (RBF) in ArcGIS GeoStatistical Analyst [(Environmental Systems Research Institute, Inc. (ESRI), Redlands, Calif., 2006, version 9.2)].

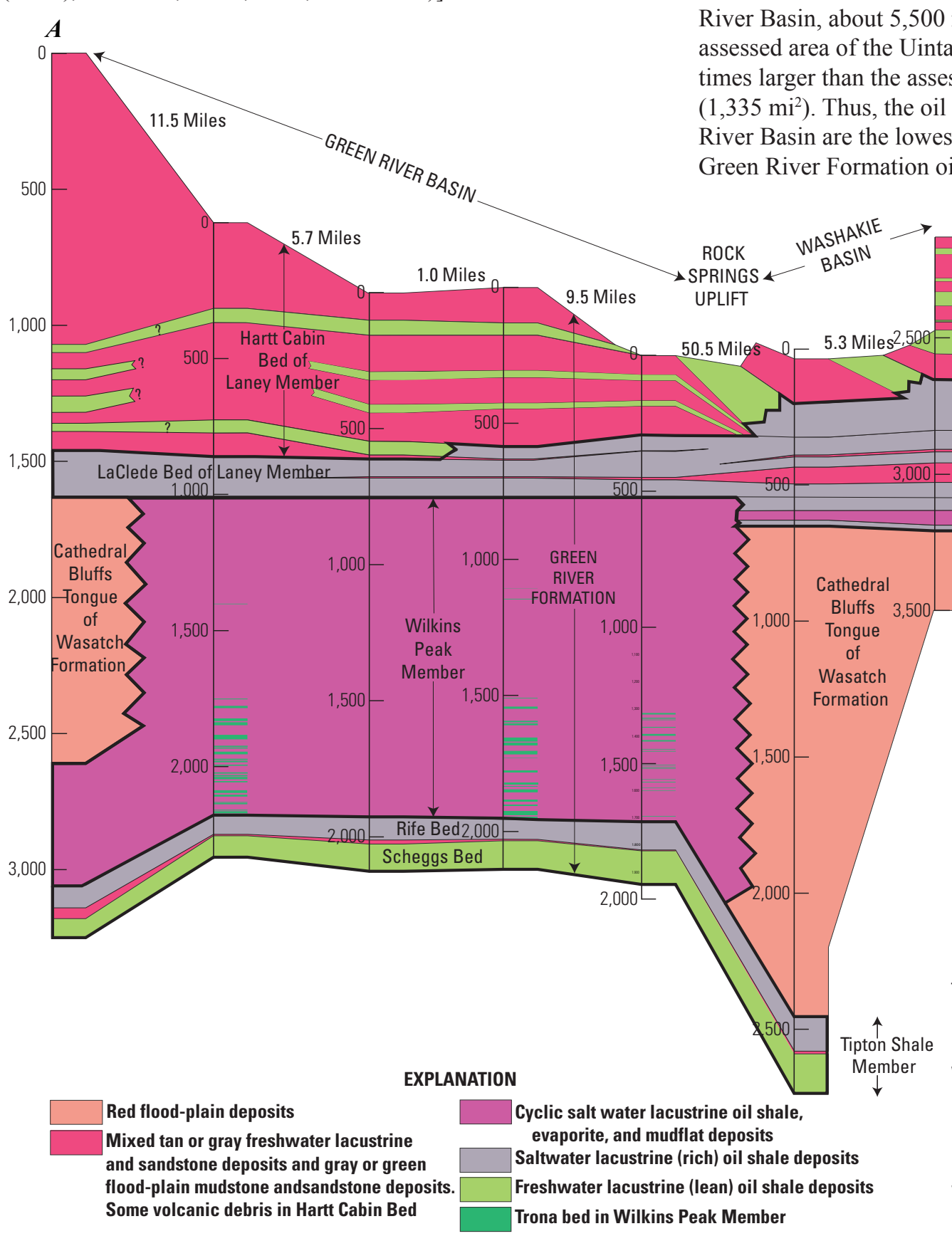

\section{Resource Summary}

The three units of the Green River Formation assessed here, in ascending order, are the Tipton Shale Member, the Wilkins Peak Member, and the LaClede Bed of the Laney Member (fig. 2). Note that the boundaries of the assessment units, particularly those for LaClede Bed and Wilkins Peak assessment units vary stratigraphically across the basin. Total in-place resources are estimated at 1.44 trillion barrels of oil divided among the three assessed units as follows: (1) Tipton Shale Member, 362,816 million barrels of oil (MMBO);

(2) Wilkins Peak Member, 704,991 MMBO; and (3) LaClede Bed of the Laney Member, 377,184 MMBO. Figure 3 shows total in-place oil in each 6-mile-square township for all three assessed units combined. This result compares with in-place resource estimates of 1.53 trillion barrels for the Piceance Basin of Colorado and of 1.32 trillion barrels for the Uinta Basin of Utah and Colorado. The assessed area of the Greater Green River Basin, about 5,500 $\mathrm{mi}^{2}$, is about 1.4 times larger than the assessed area of the Uinta Basin $\left(3,834 \mathrm{mi}^{2}\right)$ and more than four times larger than the assessed area of the Piceance Basin $\left(1,335 \mathrm{mi}^{2}\right)$. Thus, the oil shale deposits of the Greater Green River Basin are the lowest grade of the three basins that contain

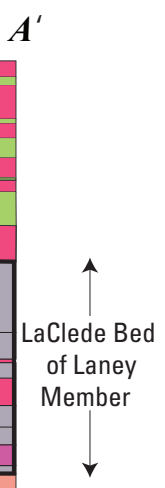

Figure 2. East-west cross section showing stratigraphic boundaries of the three oil shale units assessed (heavy black outlines) and related stratigraphic units. Note that the boundaries of the Wilkins Peak Member and the LaClede Bed of the Laney Member of the Green River Formation assessment units vary stratigraphically across the basin. Vertical lines are drillholes showing depths, in feet. 


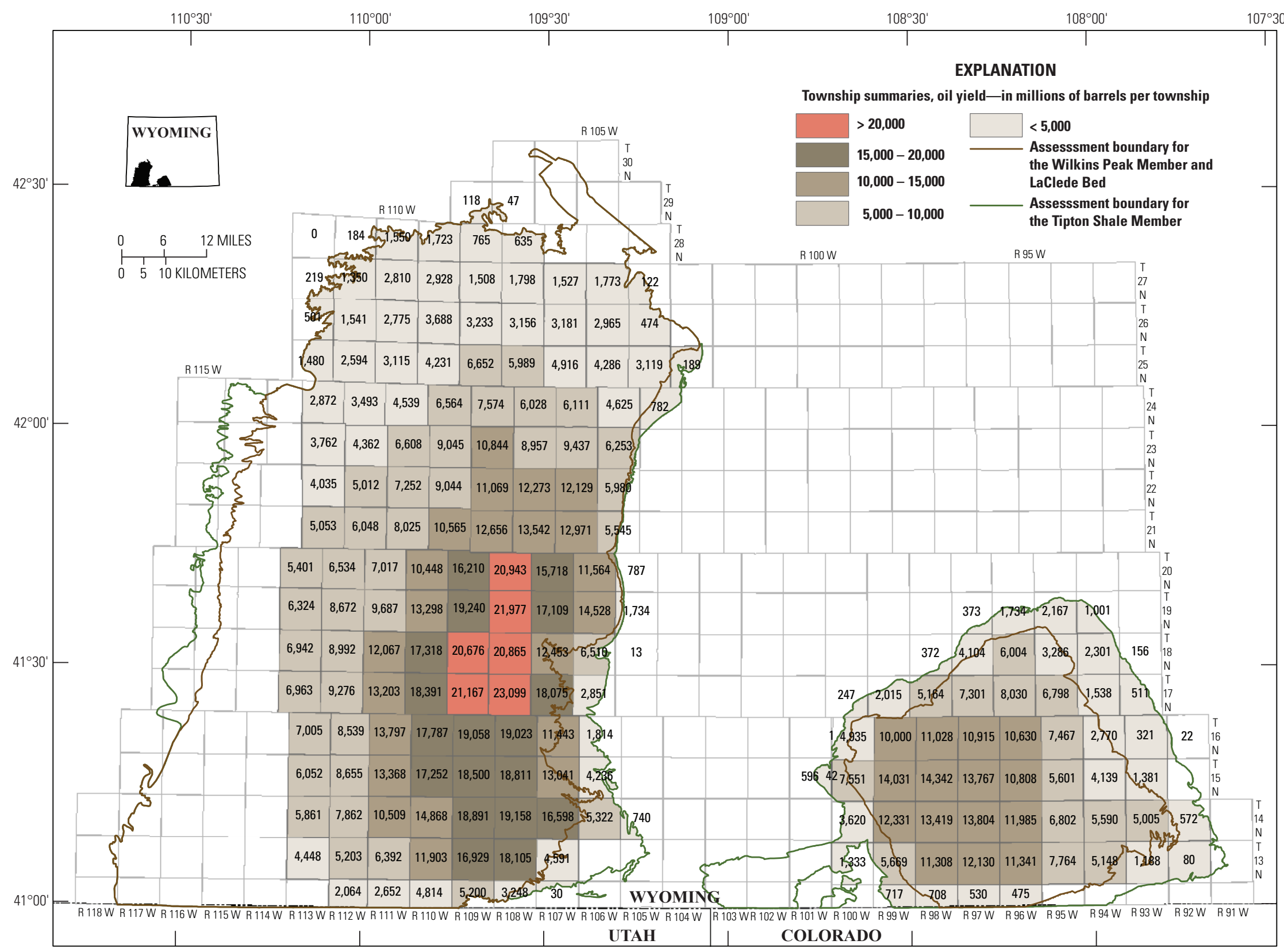

Figure 3. Map showing total in-place oil, in millions of barrels, for each township assessed in the Greater Green River Basin, Wyoming. 


\section{REFERENCES CITED}

American Society for Testing and Materials (ASTM), 1980, Standard method of test for oil from oil shale: Annual Book of ASTM Standards, Part 25, Designation D 3904-80, p. $513-515$.

Finn, T. M., Johnson, R. C., and Roberts, S. B., 2005, The Mesaverde-Lance-Fort Union composite Total Petroleum System, Southwestern Wyoming Province: U.S. Geological Survey Digital Data Series DDS-69-D, Chapter 10, 33 p.

Johnson, R.C., Mercier, T.J., Brownfield, M.E., Pantea, M.P., and Self, J.G., 2010a, An assessment of in-place oil shale resources in the Green River Formation, Piceance Basin, Colorado, in U.S. Geological Survey Oil Shale Assessment Team, eds., Oil-shale assessment of the Piceance Basin, Colorado: U.S. Geological Survey Digital Data Series DDS-69-Y, chap. 1, 197 p.

Johnson, R.C., Mercier, T.J., Brownfield, M.E., and Self, J.G., 2010b, Assessment of in-place oil shale resource of the Green River Formation, Uinta Basin, Utah, in U.S. Geological Survey Oil Shale Assessment Team, eds., Oil-shale assessment of the Uinta Basin, Utah and Colorado: U.S. Geological Survey Digital Data Series DDS-69-BB, chap. 1, 162 p.

Southwest Wyoming Province Assessment Team, 2005, The Southwestern Wyoming Province-Introduction to a geologic assessment of undiscovered oil and gas resources: U.S. Geological Survey Digital Data Series DDS-69-D, 36 p.

\section{For Additional Information}

Supporting geologic studies of the oil shale-bearing units, assessment units, oil shale analyses, and the methodology used in assessing the oil shale resources in the Greater Green River Basin are in progress. Assessment results are available at the USGS Central Energy Team website: http://energy.cr.usgs.gov/ other/oil_shale/.

\section{Contact Information}

For further information contact Ronald C. Johnson (rcjohnson@usgs.gov), T.J. Mercier(tmercier@usgs.gov), and Michael E. Brownfield (mbrownfield@usgs.gov).

Stanfield, K.E., and Frost, I.C., 1949, Method of assaying oil shale by a modified Fischer retort: U.S. Bureau of Mines Report of Investigations 4477.

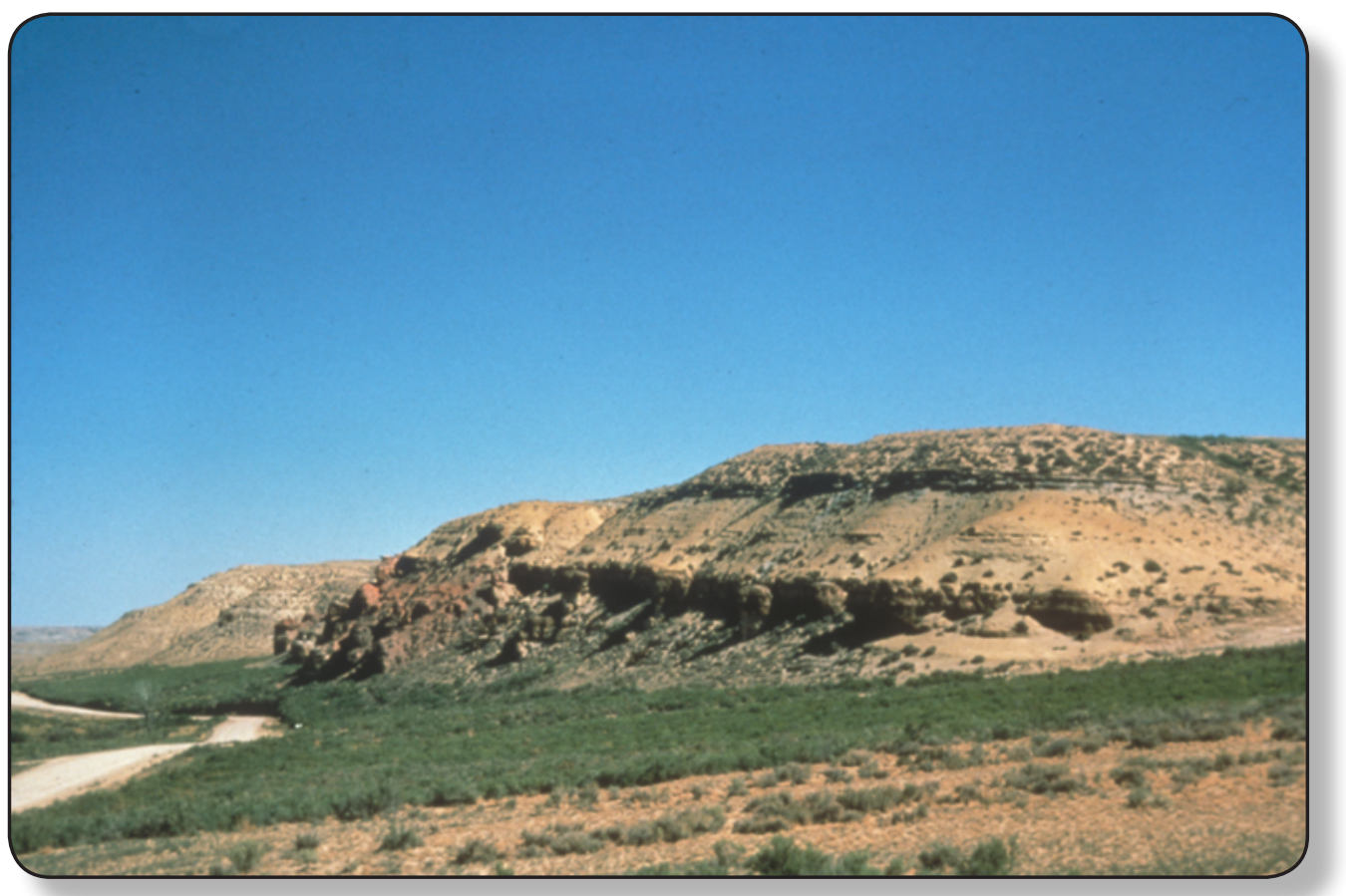

LaClede Bed of the Laney Member of the Green River Formation, north rim of the Washakie Basin, Wyoming. Photograph by John R. Donnell. 